\title{
A 10-year review of primary major salivary gland cancers
}

\author{
Andreia Cruz ${ }^{1}$, Helena Magalhães ${ }^{2}$, Filipa Ferreira Pereira ${ }^{1}$, José Dinis ${ }^{1}$ and Cláudia Vieira ${ }^{1}$ \\ ${ }^{1}$ Medical Oncology Department, Instituto Português de Oncologia do Porto, Porto, Portugal \\ ${ }^{2}$ Medical Oncology Department, Unidade Local de Saúde de Matosinhos - Hospital Pedro Hispano, Matosinhos, Portugal
}

\section{Abstract}

Primary salivary gland cancers comprise a heterogeneous group of histological entities and represent less than $5 \%$ of head and neck malignancies. Surgical resection is the main treatment, and adjuvant radiotherapy is performed in selected cases. Chemotherapy is an option in metastatic or recurrent disease, with poor evidence. We aimed to review a 10-year experience of a cancer centre on major salivary gland cancers, focusing on clinical, pathological, treatment and patients' outcomes data.

A total of 93 patients were identified, median age at diagnosis was 64 years (IQR, 23), and $51.6 \%$ were male. The parotid gland was the site of origin in $76.3 \%$ of cases. The most frequent histological type was salivary duct carcinoma (21.5\%). All patients were submitted to surgery and adjuvant radiotherapy was performed in 74.2\%. From 26 patients diagnosed with metastatic disease, 9 were treated with systemic therapy. At 8 years, disease-free survival was $54.6 \%$ and overall survival was $48.4 \%$. Male sex, salivary duct carcinoma, stage pT3-4, stage pN2-3, high histologic grade, lymphovascular invasion and perineural invasion were negative prognostic indicators for disease-free survival and overall survival. Extracapsular spread was a negative prognostic indicator for overall survival. In the multivariable analysis, histological type-salivary duct carcinoma-kept significant negative impact in disease-free survival and high histologic grade in overall survival.

The most frequent histological type was salivary duct carcinoma, which is estimated to represent only $9 \%$ of salivary tumours. Patients with salivary duct carcinoma relapsed more than other histological types. High histologic grade was a negative prognostic indicator for overall survival.

Keywords: head and neck cancer, salivary gland cancer, parotid gland

\section{Background}

Primary salivary gland cancers (SGC) are a rare and highly diverse group of tumours regarding histology, clinical behaviour and responsiveness to therapy. The incidence of SGC is estimated to be $1.31 / 100,000 /$ year, representing less than $5 \%$ of all head and neck malignancies, with equal sex distribution and average age of 47 years [1, 2].

The 2017 World Health Organization classification comprises more than 20 different malignant histologies for SGC, with specific features and outcomes. The impact of genetic alterations is increasing, despite restricted to diagnostic purposes so far [2]. Mucoepider-
Correspondence to: Andreia Cruz Email: andreia.kruz@gmail.com

ecancer 2020, 14:1055

https://doi.org/10.3332/ecancer.2020.1055

Published: $12 / 06 / 2020$

Received: 19/12/2019

Publication costs for this article were supported by ecancer (UK Charity number 1176307).

Copyright: (c) the authors; licensee ecancermedicalscience. This is an Open Access article distributed under the terms of the Creative Commons Attribution License (http:// creativecommons.org/licenses/by/3.0), which permits unrestricted use, distribution, and reproduction in any medium, provided the original work is properly cited. 
moid carcinoma is the most frequent primary salivary malignancy, followed by adenoid cystic and acinic cell carcinoma [3]. Parotid gland is the most frequent site of origin, accounting for $70 \%$ of cases, with only $10 \%$ to $15 \%$ arising in minor salivary glands. Nevertheless, malignancy rate has been described as only $25 \%$ for parotid neoplasms, compared to $82 \%$ for minor salivary glands and $43 \%$ for submandibular glands [4].

It is recognised that risk factors for SGC include viruses, radiation exposure and occupation. Prognostic factors include stage-tumour size or extent $(\mathrm{T})$, nodal status and extranodal extension $(\mathrm{N})$ and presence of distant metastases $(\mathrm{M})$-, location, histological type and grade $[5,6]$. Also, perineural and lymphovascular invasion, and even male sex have been associated with poorer outcomes [7, 8].

Currently, upfront surgical resection remains the standard of care for locoregional disease, with elective neck dissection according to histology and clinical stage [9,10]. Adjuvant radiotherapy can be performed in high grade, advanced stage disease or incomplete resection [11], apparently with no benefit from concurrent chemotherapy [12]. Chemotherapy is an option in metastatic or recurrent setting, with CAP regimen (cyclophosphamide, adriamycin and cisplatin) having the greatest amount of data, despite no clear benefit on survival or over singleagent therapy [13,14]. Hormonal therapy has shown activity in androgen-receptor positive SGC, which is detected in various histologies and in the majority of cases of salivary duct carcinoma (SDC) [15]. Also, there has been an increasing interest in defining routes to targeted therapies, with some preliminary evidence $[16,17]$.

In this study, we aim to review the incidence, pathology, clinical behaviour and outcomes in a cohort of patients with major SGC treated at a tertiary cancer centre over a 10-year period from 2006 to 2016.

\section{Methods}

A retrospective cohort of patients with histological diagnosis of primary major SGC, admitted to a single tertiary cancer centre from March 2006 to July 2016 , was evaluated.

Demographic and clinical-pathological features analysis was performed using descriptive statistics. Data were retrieved from patients' charts regarding demographics, presentation, pathology, treatment and outcomes, including disease-free survival (DFS) and overall survival (OS). DFS and OS were estimated by the Kaplan-Meier method and compared by Cox regression. DFS was defined as time between curative treatment and local or distant recurrence; OS was defined as time between diagnosis and death from any cause. Follow-up was updated as of 31th October, 2019.

Statistical analysis was performed using SPSS Statistics for MacOS, version 25.0 (SPSS, Chicago, IL). Statistical significance was set at $p<$ 0.05 .

The study was conducted in accordance with the Declaration of Helsinki on biomedical research involving human subjects, and after the written approval of institutional ethics committee.

\section{Results}

Between March 2006 and July 2016, 933 patients were diagnosed with salivary gland lesions in our institution, whose $32.9 \%(n=307)$ had malignant histologies, and 10.0\% ( $n=93)$ were primary tumours. Median follow-up was 8 years $(\mathrm{Cl} 95 \% 6.2-9.6)$. Demographics, clinicalpathological and treatment features are summarised in Table 1. Most patients were male and median age at diagnosis was 64 years (IQR, 23). The location of the primary tumour was mostly in parotid gland $(76.3 \%, n=71)$, followed by submandibular gland $(22.6 \%, n=21)$. The most frequent histological type was SDC $(21.5 \%, n=20)$, followed by adenoid cystic carcinoma $(16.1 \%, n=15)$ and mucoepidermoid carcinoma $(14.0 \%, n=13)$. Six cases of SDC $(30 \%)$ arose in pleomorphic adenoma. All patients were submitted to surgery and most of them underwent adjuvant radiotherapy $(74.2 \%, n=69)$, in three cases with concurrent chemotherapy with cisplatin. A large number of patients were diagnosed with pT3 or pT4 disease $(36.6 \%, n=34)$ and with positive lymph nodes $(18.3 \%, n=17)$ although an important number of patients $(31.2 \%, n=29)$ had no lymph nodes removed (stage $\mathrm{pNx}$ ). Eight patients were initially diagnosed with distant metastasis. Histological grade was classified as high in $24.7 \%(n=23)$ of patients. Lymphovascular invasion was seen in $22.6 \%$ of patients $(n=21)$, perineural invasion in $37.6 \%(n=35)$, carcinoma ex pleomorphic adenoma in 6.5\% $(n=6)$ and extracapsular spread in $9.7 \%(n=9)$. Facial nerve sacrifice during surgery was used as a surrogate for preoperative facial nerve involvement, and was present in $23.9 \%(n=17)$ of patients who underwent parotidectomy. ERBB2 and androgen receptor positivity was seen in two and six patients, from six and 11 analysed, respectively. 
Table 1. Demographics, clinical-pathological and treatment features.

\begin{tabular}{|c|c|c|c|}
\hline Characteristics & & $n$ & $\%$ \\
\hline Sex & $\begin{array}{l}\text { Male } \\
\text { Female }\end{array}$ & $\begin{array}{l}48 \\
45\end{array}$ & $\begin{array}{l}51.6 \\
48.4\end{array}$ \\
\hline Age & $\begin{array}{l}\text { Median, years } \\
\text { Interquartile Range, years }\end{array}$ & \multicolumn{2}{|c|}{$\begin{array}{l}64 \\
23 \\
\end{array}$} \\
\hline $\begin{array}{l}\text { Eastern Cooperative Oncology Group (ECOG) } \\
\text { performance status }\end{array}$ & $\begin{array}{l}0 \\
1 \\
2 \\
3 \\
\text { Missing }\end{array}$ & $\begin{array}{c}21 \\
5 \\
1 \\
1 \\
65\end{array}$ & $\begin{array}{c}22.6 \\
5.4 \\
1.1 \\
1.1 \\
65.9\end{array}$ \\
\hline Primary site & $\begin{array}{l}\text { Parotid gland } \\
\text { Submandibular gland } \\
\text { Sublingual gland }\end{array}$ & $\begin{array}{c}71 \\
21 \\
1 \\
\end{array}$ & $\begin{array}{c}76.3 \\
22.6 \\
1.1 \\
\end{array}$ \\
\hline Histological type & $\begin{array}{l}\text { Salivary duct carcinoma } \\
\text { Adenoid cystic carcinoma } \\
\text { Mucoepidermoid carcinoma } \\
\text { Myoepithelial carcinoma } \\
\text { Acinic cell carcinoma } \\
\text { Carcinoma ex pleomorphic adenoma } \\
\text { Squamous cell carcinoma } \\
\text { Oncocytic carcinoma } \\
\text { Basal cell adenocarcinoma } \\
\text { Adenocarcinoma, not otherwise specified } \\
\text { Small cell carcinoma } \\
\text { Carcinosarcoma } \\
\text { Low-grade cribriform cystadenocarcinoma } \\
\text { Solitary fibrous tumour }\end{array}$ & $\begin{array}{l}20 \\
15 \\
13 \\
11 \\
9 \\
6 \\
6 \\
3 \\
3 \\
3 \\
1 \\
1 \\
1 \\
1\end{array}$ & $\begin{array}{l}21.5 \\
16.1 \\
14.0 \\
11.8 \\
9.7 \\
6.5 \\
6.5 \\
3.2 \\
3.2 \\
3.2 \\
1.1 \\
1.1 \\
1.1 \\
1.1\end{array}$ \\
\hline Stage T & $\begin{array}{l}\text { pT1 } \\
\text { pT2 } \\
\text { pT3 } \\
\text { pT4 } \\
\text { Missing }\end{array}$ & $\begin{array}{c}26 \\
27 \\
22 \\
12 \\
6\end{array}$ & $\begin{array}{c}28.0 \\
29.0 \\
23.7 \\
12.9 \\
6.5\end{array}$ \\
\hline Stage N & $\begin{array}{l}\text { pN0 } \\
\text { pN1 } \\
\text { pN2 } \\
\text { pN3 } \\
\text { pNx } \\
\text { Missing }\end{array}$ & $\begin{array}{c}41 \\
6 \\
8 \\
3 \\
29 \\
6\end{array}$ & $\begin{array}{c}44.1 \\
6.5 \\
8.6 \\
3.2 \\
31.2 \\
6.5 \\
\end{array}$ \\
\hline Stage M & $\begin{array}{l}\text { cM0 } \\
\text { cM1 } \\
\text { Missing }\end{array}$ & $\begin{array}{c}82 \\
8 \\
3 \\
\end{array}$ & $\begin{array}{c}88.2 \\
8.6 \\
3.2 \\
\end{array}$ \\
\hline Grade & $\begin{array}{l}\text { High } \\
\text { Intermediate } \\
\text { Low } \\
\text { Missing }\end{array}$ & $\begin{array}{c}23 \\
8 \\
17 \\
45\end{array}$ & $\begin{array}{c}24.7 \\
8.6 \\
18.3 \\
48.4\end{array}$ \\
\hline
\end{tabular}


Table 1. Continued

\begin{tabular}{|c|c|c|c|}
\hline Characteristics & & $n$ & $\%$ \\
\hline Lymphovascular invasion & $\begin{array}{l}\text { Yes } \\
\text { No } \\
\text { Missing }\end{array}$ & $\begin{array}{l}21 \\
48 \\
24\end{array}$ & $\begin{array}{l}22.6 \\
51.6 \\
25.8\end{array}$ \\
\hline Perineural invasion & $\begin{array}{l}\text { Yes } \\
\text { No } \\
\text { Missing }\end{array}$ & $\begin{array}{l}35 \\
37 \\
21 \\
\end{array}$ & $\begin{array}{l}37.6 \\
39.8 \\
22.6 \\
\end{array}$ \\
\hline Carcinoma ex pleomorphic & $\begin{array}{l}\text { Yes } \\
\text { No } \\
\text { Missing }\end{array}$ & $\begin{array}{c}6 \\
55 \\
32\end{array}$ & $\begin{array}{c}6.5 \\
59.1 \\
34.4\end{array}$ \\
\hline Extracapsular spread & $\begin{array}{l}\text { Yes } \\
\text { No } \\
\text { Missing }\end{array}$ & $\begin{array}{c}9 \\
52 \\
32\end{array}$ & $\begin{array}{c}9.7 \\
55.9 \\
34.4\end{array}$ \\
\hline Facial nerve sacrifice & $\begin{array}{l}\text { Yes } \\
\text { No } \\
\text { Missing }\end{array}$ & $\begin{array}{c}17 \\
45 \\
9\end{array}$ & $\begin{array}{l}23.9 \\
63.4 \\
12.7\end{array}$ \\
\hline ERBB2 status & $\begin{array}{l}\text { Positive } \\
\text { Negative } \\
\text { Missing }\end{array}$ & $\begin{array}{c}2 \\
4 \\
87\end{array}$ & $\begin{array}{l}2.2 \\
4.3 \\
93.5\end{array}$ \\
\hline Androgen receptor status & $\begin{array}{l}\text { Positive } \\
\text { Negative } \\
\text { Missing }\end{array}$ & $\begin{array}{c}6 \\
5 \\
82\end{array}$ & $\begin{array}{c}6.5 \\
5.4 \\
88.2\end{array}$ \\
\hline Local treatment & $\begin{array}{l}\text { Surgery } \\
\text { Adjuvant radiotherapy } \\
\text { Adjuvant chemoradiotherapy }\end{array}$ & $\begin{array}{c}93 \\
66 \\
3\end{array}$ & $\begin{array}{c}100 \\
71 \\
3.2\end{array}$ \\
\hline Systemic treatment & $\begin{array}{l}\text { Adjuvant chemotherapy } \\
\text { Palliative chemotherapy }\end{array}$ & $\begin{array}{l}1 \\
9\end{array}$ & $\begin{array}{l}1.1 \\
9.7\end{array}$ \\
\hline
\end{tabular}

Distant metastasis at diagnosis were mainly seen in lung (four patients), but also in brain, bone, liver and skin, in one patient each. During follow-up, 34.1\% $(n=29)$ of patients recurred, mainly locally $(37.9 \%, n=11)$, but also in lung $(17.2 \%, n=5)$, bone $(10.3 \%, n=3)$, liver $(10.3 \%$, $n=3)$, brain $(3.4 \%, n=1)$ and multiple sites $(20.7 \%, n=6)$. In the metastatic setting, nine patients were treated with systemic therapy, and chemotherapy regimens used were CAP and carboplatin with paclitaxel; one patient was treated with methotrexate in third line; and the patient with small cell carcinoma was treated with carboplatin and etoposide.

At 8 years, DFS was $54.6 \%$ and OS was $48.4 \%$ (Figure 1). The results of univariate Kaplan-Meier survival analyses are summarised in Table 2 , and multivariable survival models in Table 3. In the univariate analysis, male sex, SDC, stage pT3-4, stage pN2-3, high histologic grade, lymphovascular invasion and perineural invasion were significant negative prognostic indicators for DFS and OS. Extracapsular spread was a significant negative prognostic indicator for OS, but not for DFS. In the multivariable analysis just histological type-SDC-kept significant negative impact in DFS, but not in OS; and high histologic grade in OS, but not in DFS.

\section{Discussion}

Primary SGC are rare and heterogeneous, and there is also some geographic variation in the frequency of tumour types, resulting in poorly documented epidemiology [2]. The incidence of major SGC is increasing, mainly parotid and smaller tumours, with regional and distant metastasis, probably due to earlier diagnosis and improved clinical staging. Aetiology and risk factors are not well established, thus the reason for this rising incidence is not well known [18]. Since Portugal is a small country accounting, approximately, 10 million inhabitants, and our institution is the biggest in the country dedicated to the treatment of cancer, we present, probably, the largest national series of major SGC patients. 

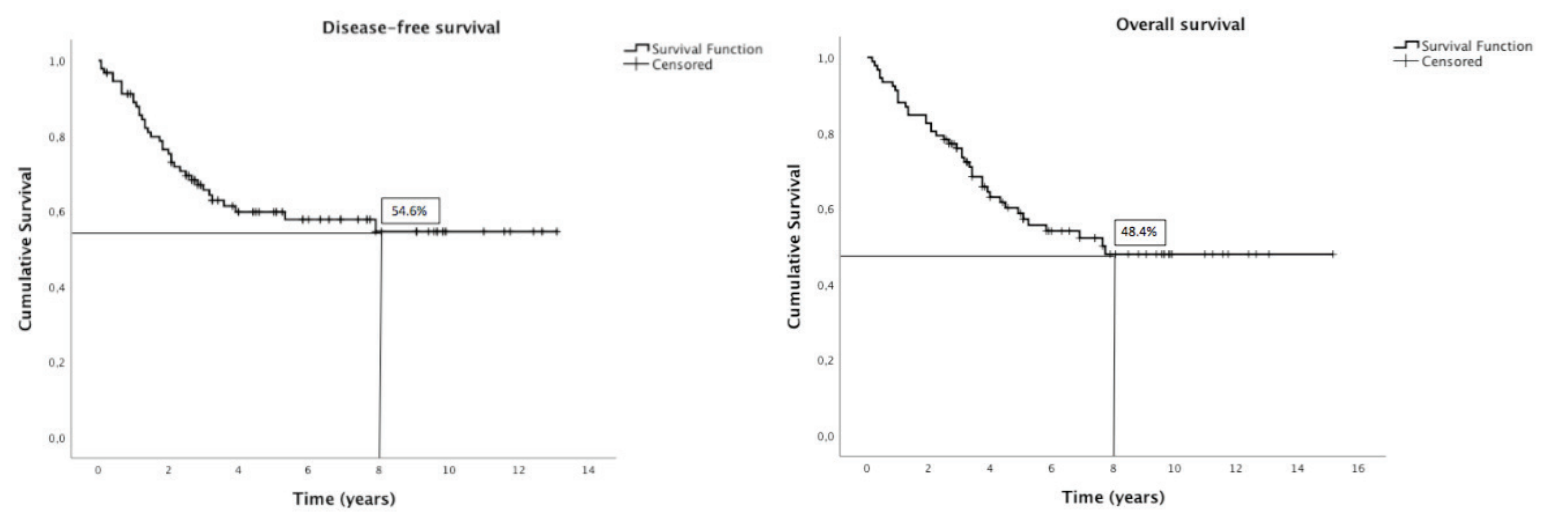

Figure 1. Kaplan-Meier plots of disease-free and overall survival.

Table 2. Univariate analysis of DFS and OS.

\begin{tabular}{|c|c|c|c|c|c|}
\hline \multirow{2}{*}{\multicolumn{2}{|c|}{ Characteristic }} & \multicolumn{2}{|c|}{ DFS, years } & \multicolumn{2}{|c|}{ OS, years } \\
\hline & & Median & $p$ & Median & $p$ \\
\hline Sex & $\begin{array}{l}\text { Male } \\
\text { Female }\end{array}$ & $\begin{array}{l}3.0 \\
N R\end{array}$ & 0.015 & $\begin{array}{l}4.9 \\
N R\end{array}$ & 0.047 \\
\hline Age, years & $\begin{array}{l}<65 \\
\geq 65\end{array}$ & $\begin{array}{l}\text { NR } \\
7.9\end{array}$ & 0.225 & $\begin{array}{l}N R \\
4.3\end{array}$ & 0.098 \\
\hline Primary site & $\begin{array}{l}\text { Parotid gland } \\
\text { Other }\end{array}$ & $\begin{array}{l}\text { NR } \\
\text { NR }\end{array}$ & 0.990 & $\begin{array}{l}7.7 \\
N R\end{array}$ & 0.510 \\
\hline Histological type & $\begin{array}{l}\text { Salivary duct carcinoma } \\
\text { Other }\end{array}$ & $\begin{array}{l}1.8 \\
N R\end{array}$ & $<0.001$ & $\begin{array}{l}3.1 \\
N R\end{array}$ & $<0.001$ \\
\hline Stage T & $\begin{array}{l}\text { pT1-2 } \\
\text { pT3-4 }\end{array}$ & $\begin{array}{l}\text { NR } \\
3.2\end{array}$ & 0.023 & $\begin{array}{l}\text { NR } \\
3.4\end{array}$ & 0.001 \\
\hline Stage N & $\begin{array}{l}\text { pNO-1 } \\
\text { pN2-3 }\end{array}$ & $\begin{array}{l}\text { NR } \\
2.8\end{array}$ & $<0.001$ & $\begin{array}{l}7.8 \\
2.5\end{array}$ & $<0.001$ \\
\hline Grade & $\begin{array}{l}\text { High } \\
\text { Intermediate/Low }\end{array}$ & $\begin{array}{l}1.8 \\
N R\end{array}$ & $<0.001$ & $\begin{array}{l}3.1 \\
N R\end{array}$ & $<0.001$ \\
\hline Lymphovascular invasion & $\begin{array}{l}\text { Yes } \\
\text { No }\end{array}$ & $\begin{array}{l}2.0 \\
N R\end{array}$ & 0.001 & $\begin{array}{l}3.2 \\
N R\end{array}$ & 0.001 \\
\hline Perineural invasion & $\begin{array}{l}\text { Yes } \\
\text { No }\end{array}$ & $\begin{array}{l}3.6 \\
N R\end{array}$ & 0.028 & $\begin{array}{l}4.0 \\
N R\end{array}$ & 0.004 \\
\hline Carcinoma ex pleomorphic & $\begin{array}{l}\text { Yes } \\
\text { No }\end{array}$ & $\begin{array}{l}\text { NR } \\
\text { NR }\end{array}$ & 0.283 & $\begin{array}{l}4.9 \\
7.7\end{array}$ & 0.322 \\
\hline Extracapsular spread & $\begin{array}{l}\text { Yes } \\
\text { No }\end{array}$ & $\begin{array}{l}3.0 \\
N R\end{array}$ & 0.094 & $\begin{array}{l}2.5 \\
N R\end{array}$ & $<0.001$ \\
\hline Facial nerve sacrifice & $\begin{array}{l}\text { Yes } \\
\text { No }\end{array}$ & $\begin{array}{l}3.2 \\
N R\end{array}$ & 0.613 & $\begin{array}{l}4.9 \\
N R\end{array}$ & 0.509 \\
\hline ERBB2 status & $\begin{array}{l}\text { Positive } \\
\text { Negative }\end{array}$ & $\begin{array}{l}1.8 \\
1.3\end{array}$ & 0.782 & $\begin{array}{l}5.1 \\
3.2\end{array}$ & 0.317 \\
\hline Androgen receptor status & $\begin{array}{l}\text { Positive } \\
\text { Negative }\end{array}$ & $\begin{array}{l}1.8 \\
N R\end{array}$ & 0.682 & $\begin{array}{l}3.2 \\
5.3\end{array}$ & 0.578 \\
\hline
\end{tabular}


Table 3. Multivariable analysis of DFS and OS.

\begin{tabular}{|c|c|c|c|c|c|}
\hline \multirow{2}{*}{\multicolumn{2}{|c|}{ Characteristics }} & \multicolumn{2}{|c|}{ DFS } & \multicolumn{2}{|c|}{ OS } \\
\hline & & \multirow{2}{*}{$\begin{array}{c}\text { HR } \\
(95 \% \mathrm{Cl})\end{array}$} & \multirow{2}{*}{$\begin{array}{c}\mathbf{p} \\
0.057\end{array}$} & \multirow{2}{*}{$\begin{array}{c}\text { HR } \\
(95 \% \mathrm{Cl}) \\
3.2 \\
(0.4-26.4)\end{array}$} & \multirow{2}{*}{$\begin{array}{c}\mathbf{p} \\
0.28\end{array}$} \\
\hline Sex & $\begin{array}{l}\text { Male } \\
\text { Female }\end{array}$ & & & & \\
\hline Histological type & $\begin{array}{l}\text { Salivary duct carcinoma } \\
\text { Other }\end{array}$ & $\begin{array}{c}43.5 \\
(1.1-1686.1)\end{array}$ & 0.043 & $\begin{array}{c}6.1 \\
(0.2-201.1)\end{array}$ & 0.310 \\
\hline Stage T & $\begin{array}{l}\text { pT1-2 } \\
\text { pT3-4 }\end{array}$ & $\begin{array}{c}0.72 \\
(0.06-8.7)\end{array}$ & 0.800 & $\begin{array}{c}0.05 \\
(0.0-2.4)\end{array}$ & 0.132 \\
\hline Stage N & $\begin{array}{l}\text { pN0-1 } \\
\text { pN2-3 }\end{array}$ & $\begin{array}{c}0.45 \\
(0.02-11.1)\end{array}$ & 0.624 & $\begin{array}{c}9.6 \\
(0.1-1492.9)\end{array}$ & 0.379 \\
\hline Grade & $\begin{array}{l}\text { High } \\
\text { Intermediate/Low }\end{array}$ & $\begin{array}{c}0.0 \\
(0.0-6965.0)\end{array}$ & 0.936 & $\begin{array}{c}0.02 \\
(0.001-0.9)\end{array}$ & 0.044 \\
\hline Lymphovascular invasion & $\begin{array}{l}\text { Yes } \\
\text { No }\end{array}$ & $\begin{array}{c}0.13 \\
(0.01-1.8)\end{array}$ & 0.129 & $\begin{array}{c}0.35 \\
(0.02-6.9)\end{array}$ & 0.488 \\
\hline Perineural invasion & $\begin{array}{l}\text { Yes } \\
\text { No }\end{array}$ & $\begin{array}{c}7.4 \\
(0.4-127.9)\end{array}$ & 0.167 & $\begin{array}{c}0.57 \\
(0.06-5.3)\end{array}$ & 0.623 \\
\hline Extracapsular spread & $\begin{array}{l}\text { Yes } \\
\text { No }\end{array}$ & NA & & $\begin{array}{c}0.02 \\
(0.0-1.5)\end{array}$ & 0.075 \\
\hline
\end{tabular}

In our cohort, the most frequent histological type was SDC, which is estimated to represent only $9 \%$ of salivary tumours [2], probably because our institution is a high-specialised oncology centre. Kleinsasser et al [19] described SDC in 1968, as an aggressive adenocarcinoma which resembles high-grade breast ductal carcinoma. This entity has been increasingly diagnosed, and there is currently a growing interest from the scientific community, with multiple publications of institutional series [20-30]. Actually, SDC is characterised by a very aggressive behaviour, with high rates of local or distant recurrence and tumour-related death [31,32]. This is mostly diagnosed in elderly men, predominantly in the parotid gland. Pain, facial palsy and presence of calcifications on computed tomography scans are suggestive features of SDC. Node metastasis, lymphovascular and perineural invasion, and positive surgical margins have been described as adverse prognostic factors [31, 32]. SDC frequently overexpresses EGFR and ERBB2, but it is not clear whether that expression is associated with poor prognosis, or the role of targeted therapy [33]. Trastuzumab, an inhibitor of ERBB2, has been used for systemic therapy in patients with advanced SDC with promising responses [34-37]. SDC is also associated with androgen-receptor positivity in $67 \%-96 \%$ of cases, and, recently, a prospective phase II study showed that combined androgen blockade had equivalent efficacy and less toxicity for patients with androgen-receptor positive recurrent/ metastatic or unresectable locally advanced SGC compared with conventional chemotherapy, which warrants further investigation [38-40]. Even PD-L1 expression and its correlation with survival and other promising therapeutic targets are under investigation in SDC and other histologies of SGC $[41,42]$.

In our cohort, patients with SDC relapsed more, and high histologic grade was a negative prognostic indicator for overall survival, which is in accordance with previous data. Only few patients were treated with palliative chemotherapy, due to its modesty activity. Data on the role of systemic therapy in the management of SGC is limited, and chemotherapy is generally reserved for advanced disease, when it is not suitable to surgery and/or radiation [13]. A systematic review of published data in the management of metastatic or locally recurrent adenoid cystic SGC demonstrated major objective responses in nine of 36 patients treated with CAP regimen (response rate $25 \%, 95 \% \mathrm{Cl} 11 \%-39 \%$ ), but even in just four trials analysed, doses were different [43]. We had an adenoid cystic SGC patient with almost 3 years of progression-free survival after first line chemotherapy with CAP regimen for lung recurrence $\left(500 / 50 / 50 \mathrm{mg} / \mathrm{m}^{2}\right.$, q21d, six cycles). Despite the lack of robust data to support carboplatin-based regimens, we used it in combination with paclitaxel $[44,45]$, with manageable toxicity profile and progression- 
free survival between two and 28 months. A small number of patients were submitted to ERBB2 and androgen receptor status determination and none was treated with targeted therapy, despite the positivity rate of $33.3 \%$ and $54.5 \%$, respectively.

The present study was limited by its retrospective design and a small number of patients included, with multiple histologies. Prospective clinical trials, including those analysing the efficacy of adjuvant therapy and targeted therapy, are warranted. Priority should be given, also, to the molecular understanding of these tumours. Nevertheless, due to SGC rarity, such studies will be difficult to perform, and we must start to analyse what we have now, to aggregate multicenter data and set priorities for the future.

\section{Conclusions}

In our cohort, the most frequent histological type was SDC, which is estimated to represent only 9\% of salivary tumours [2]. Patients with SDC relapsed more, and high histologic grade was a negative prognostic indicator for overall survival. Only a few patients were treated with palliative chemotherapy, mainly with CAP regimen or combined carboplatin and paclitaxel.

\section{Conflicts of interest}

The authors declare no conflicts of interest

\section{Funding statement}

There was no funding for this study.

\section{References}

1. Gatta G, van der Zwan JM, and Siesling S, et al (2010) Technical report with basic indicators for rare cancers and health care related macro indicators Rarecare 5 (13) 24

2. El-Naggar AK, Chan JK, and Grandis JR, et al (2017) WHO Classification of Head and Neck Tumours (Lyon: International Agency for Research on Cancer)

3. Boukheris H, Curtis RE, and Land CE, et al (2009) Incidence of carcinoma of the major salivary glands according to the WHO classification, 1992 to 2006: a population-based study in the United States Cancer Epidemiol Biomarkers Prev 18 2899-2906 https://doi. org/10.1158/1055-9965.EPI-09-0638 PMID: 19861510 PMCID: 2779732

4. Spiro RH (1986) Salivary neoplasms: overview of a 35-year experience with 2,807 patients Head Neck Surg 8 (3) 177-184 https://doi. org/10.1002/hed.2890080309 PMID: 3744850

5. Jegadeesh N, Liu Y, and Prabhu RS, et al (2015) Outcomes and prognostic factors in modern era management of major salivary gland cancer Oral Oncol 51 770-777 https://doi.org/10.1016/j.oraloncology.2015.05.005 PMID: 26033470 PMCID: 4515354

6. Seethala RR, Altemani A, and Ferris RL, et al (2019) Data set for the reporting of carcinomas of the major salivary glands Arch Pathol Lab Med 143 578-586 https://doi.org/10.5858/arpa.2018-0422-SA

7. Israel Y, Rachmiel A, and Gourevich K, et al (2019) Kaplan-Meier analysis of salivary gland tumors: prognosis and long-term survival J Cancer Res Clin Oncol [Epub ahead of print] https://doi.org/10.1007/s00432-019-02953-9

8. Mimica X, McGill M, and Hay A, et al (2019) Sex disparities in salivary malignancies: does female sex impact oncological outcome? Oral Oncol 94 86-92 https://doi.org/10.1016/j.oraloncology.2019.05.017 PMID: 31178218 PMCID: 6559377 
9. Mantravadi AV, Moore MG, and Rassekh CH (2019) AHNS series: do you know your guidelines? Diagnosis and management of salivary gland tumors Head Neck 41(2) 269-280

10. Son E, Panwar A, and Mosher CH, et al (2018) Cancers of the major salivary gland J Oncol Pract 14(2) 99-108 https://doi.org/10.1200/ JOP.2017.026856 PMID: 29436307

11. Terhaard $\mathrm{CHJ}$, Lubsen $\mathrm{H}$, and Rasch $\mathrm{CRN}$, et al (2005) The role of radiotherapy in the treatment of malignant salivary gland tumors Int J Radiation Oncol Biol Phys 61(1) 103-111 https://doi.org/10.1016/j.jirobp.2004.03.018

12. Amini A, Waxweiler TV, and Brower JV, et al (2016) Association of adjuvant chemoradiotherapy vs radiotherapy alone with survival in patients with resected major salivary gland carcinoma-data from the National Cancer Data Base JAMA Otolaryngol Head Neck Surg 142(11) 1100-1110 https://doi.org/10.1001/jamaoto.2016.2168 PMID: 27541166

13. Laurie SA and Licitra L (2006) Systemic therapy in the palliative management of advanced salivary gland cancers J Clin Oncol 24 26732678 https://doi.org/10.1200/JCO.2005.05.3025 PMID: 16763282

14. Alfieri S, Granata R, and Bergamini C, et al (2017) Systemic therapy in metastatic salivary gland carcinomas: a pathology-driven paradigm? Oral Oncol 66 58-63 https://doi.org/10.1016/j.oraloncology.2016.12.016 PMID: 28249649

15. Dalin MG, Watson PA, and Ho AL, et al (2017) Androgen receptor signaling in salivary gland cancer Cancers 917 https://doi.org/10.3390/ cancers9020017 PMCID: 5332940

16. Ross JS, Gay LM, and Wang K, et al (2017) Comprehensive genomic profiles of metastatic and relapsed salivary gland carcinomas are associated with tumor type and reveal new routes to targeted therapies Ann Oncol 28(10) 2539-2546 https://doi.org/10.1093/ annonc/mdx399 PMID: 28961851 PMCID: 5834110

17. Cavalieri S, Platini F, and Bergamini C, et al (2019) Genomics in non-adenoid cystic group of salivary gland cancers: one or more druggable entities? Expert Opin Investig Drugs 28(5) 435-443 https://doi.org/10.1080/13543784.2019.1598376 PMID: 30897975

18. Del Signore AG and Megwalu UC (2017) The rising incidence of major salivary gland cancer in the United States. Ear Nose Throat J 96(3) E13-E16 https://doi.org/10.1177/014556131709600319 PMID: 28346649

19. Kleinsasser O, Klein HJ, and Hubner G (1968) Salivary duct carcinoma. A group of salivary gland tumors analogous to mammary duct carcinoma Archiv Klin Exper Ohren Nasen Kehlkopfheilk 192 100-115 https://doi.org/10.1007/BF00301495

20. Stodulski D, Mikaszewski B, and Majewska H, et al (2019) Parotid salivary duct carcinoma: a single institution's 20-year experience Eur Arch Otorhinolaryngol [Epub ahead of print] https://doi.org/10.1007/s00405-019-05454-0

21. Villepelet A, Lefèvre M, and Verillaud B, et al (2019) Salivary duct carcinoma: prospective multicenter study of 61 cases of the Réseau d'Expertise Français des Cancers ORL Rares Head Neck 41(3) 584-591 https://doi.org/10.1002/hed.25194

22. Anwer AW, Faisal M, and Adeel M, et al (2018) Clinicopathological behavior and treatment-related outcome of rare salivary duct carcinoma: the Shaukat Khanum Memorial Cancer Hospital experience Cureus 10(8) e3139 PMID: 30345196 PMCID: 6188220

23. Beck ACC, Lohuis PJFM, and Al-Mamgani A, et al (2018) Salivary duct carcinoma: evaluation of treatment and outcome in a tertiary referral institute Eur Arch Otorhinolaryngol 275(7) 1885-1892 https://doi.org/10.1007/s00405-018-5000-x PMID: 29785551

24. Boon E, Bel M, and van Boxtel W, et al (2018) A clinicopathological study and prognostic factor analysis of 177 salivary duct carcinoma patients from The Netherlands Int J Cancer 143(4) 758-766 https://doi.org/10.1002/ijc.31353 PMID: 29492965 PMCID: 6055864

25. D'heygere E, Meulemans J, and Vander Poorten V (2018) Salivary duct carcinoma Curr Opin Otolaryngol Head Neck Surg 26(2) 142-151 https://doi.org/10.1097/M00.0000000000000436 PMID: 29373327

26. Osborn V, Givi B, and Lee A, et al (2017) Characterization, treatment and outcomes of salivary ductal carcinoma using the National Cancer Database Oral Oncol 71 41-46 https://doi.org/10.1016/j.oraloncology.2017.05.005 PMID: 28688689 
27. Gilbert MR, Sharma A, and Schmitt NC, et al (2016) A 20-year review of 75 cases of salivary duct carcinoma JAMA Otolaryngol-Head Neck Surg 142 489-495 https://doi.org/10.1001/jamaoto.2015.3930 PMID: 26939990 PMCID: 5033043

28. Otsuka K, Imanishi Y, and Tada Y, et al (2016) Clinical outcomes and prognostic factors for salivary duct carcinoma: a multi-institutional analysis of 141 patients Ann Surg Oncol 23 2038-2045 https://doi.org/10.1245/s10434-015-5082-2 PMID: 26790669 PMCID: 4858547

29. Jayaprakash V, Merzianu M, and Warren GW, et al (2014) Survival rates and prognostic factors for infiltrating salivary duct carcinoma: analysis of 228 cases from the Surveillance, Epidemiology, and End Results database Head Neck 36(5) 694-701 https://doi. org/10.1002/hed.23350

30. Roh JL, Lee Jl, and Choi SH, et al (2014) Prognostic factors and oncologic outcomes of 56 salivary duct carcinoma patients in a single institution: high rate of systemic failure warrants targeted therapy Oral Oncol 50(11) e64-e66 https://doi.org/10.1016/j. oraloncology.2014.08.010 PMID: 25218000

31. Schmitt NC, Kang H, and Sharma A (2017) Salivary duct carcinoma: an aggressive salivary gland malignancy with opportunities for targeted therapy Oral Oncol 74 40-48 https://doi.org/10.1016/j.oraloncology.2017.09.008 PMID: 29103750 PMCID: 5685667

32. Johnston ML, Huang SH, and Waldron JN, et al (2015) Salivary duct carcinoma: treatment, outcomes, and patterns of failure. Head Neck [published online April 27, 2015] PMID: 25916947

33. Takase S, Kano S, and Tada Y, et al (2017) Biomarker immunoprofile in salivary duct carcinomas: clinicopathological and prognostic implications with evaluation of the revised classification. Oncotarget 8(35) 59023-59035 https://doi.org/10.18632/oncotarget.19812 PMID: 28938615 PMCID: $\underline{5601711}$

34. Wu S, Quan R, and Han L (2019) Trastuzumab-based therapy is effective for salivary duct carcinoma: case report and review of the literature Oral Oncol 91 121-122 https://doi.org/10.1016/j.oraloncology.2019.02.015 PMID: 30827840

35. Takahashi H, Tada Y, and Saotome T, et al (2019) Phase II trial of Trastuzumab and Docetaxel in patients with Human Epidermal Growth Factor Receptor 2-positive salivary duct carcinoma J Clin Oncol 37(2) 125-134 https://doi.org/10.1200/JCO.18.00545

36. Park JC, Ma TM, and Rooper L, et al (2018) Exceptional responses to pertuzumab, trastuzumab, and docetaxel in human epidermal growth factor receptor-2 high expressing salivary duct carcinomas Head Neck 40(12) E100-E106 https://doi.org/10.1002/hed.25392 PMID: 30478962

37. Saintigny P, Mitani Y, and Pytynia KB, et al (2018) Frequent PTEN loss and differential HER2/PI3K signaling pathway alterations in salivary duct carcinoma: implications for targeted therapy Cancer 124(18) 3693-3705 https://doi.org/10.1002/cncr.31600 PMID: 30289966 PMCID: 6176717

38. Udager AM and Chiosea Al (2017) Salivary duct carcinoma: an update on morphologic mimics and diagnostic use of androgen receptor immunohistochemistry. Head Neck Pathol 11(3) 288-294 https://doi.org/10.1007/s12105-017-0798-x PMID: 28321773 PMCID: 5550399

39. Fushimi C, Tada Y, and Takahashi $\mathrm{H}$, et al (2018) A prospective phase II study of combined androgen blockade in patients with androgen receptor-positive metastatic or locally advanced unresectable salivary gland carcinoma Ann Oncol 29(4) 979-984 https://doi. org/10.1093/annonc/mdx771 PMCID: 5913639

40. van Boxtel W, Locati LD, and van Engen-van Grunsven ACH, et al (2019) Adjuvant androgen deprivation therapy for poor-risk, androgen receptor-positive salivary duct carcinoma Eur J Cancer 110 62-70 https://doi.org/10.1016/j.ejca.2018.12.035 PMID: 30771738

41. Hamza A, Roberts D, and Su S, et al (2019) PD-L1 expression by immunohistochemistry in salivary duct carcinoma Ann Diagn Pathol 40 49-52 https://doi.org/10.1016/j.anndiagpath.2019.04.001 PMID: 30978575 PMCID: 6599643 
42. Nakano T, Takizawa K, and Uezato A, et al (2019) Prognostic value of programed death ligand-1 and ligand-2 co-expression in salivary gland carcinomas Oral Oncol 90 30-37 https://doi.org/10.1016/j.oraloncology.2019.01.015 PMID: 30846173

43. Laurie SA, Ho AL, and Fury MG, et al (2011) Systemic therapy in the management of metastatic or locally recurrent adenoid cystic carcinoma of the salivary glands: a systematic review. Lancet Oncol 12(8) 815-824 https://doi.org/10.1016/S1470-2045(10)70245-X

44. Airoldi M, Fornari G, and Fedani F, et al (2000) Paclitaxel and carboplatin for recurrent salivary gland malignancies Anticancer Res 20 3781-3784

45. Ruzich JC, Ciesla MC, and Clark JL (2002) Response to paclitaxel and carboplatin in metastatic salivary gland cancer: a case report Head Neck 24 406-410 https://doi.org/10.1002/hed.10034 PMID: 11933184 